\title{
Morphodynamics and spatial distribution of regional slope failures in the Offshore Amazon Basin, Brazilian Equatorial Margin
}

Natalia Caldas Albuquerque (School of Oceanography/UERJ), Antônio Tadeu dos Reis (School of Oceanography/UERJ), Silvia Ceramicola (Istituto Nazionale di Oceanografia e di Geofisica Sperimentale/OGS), Cleverson Guizan Silva (LAGEMAR/UFF), Alberto Machado Cruz (UPMC/Sorbonne Universités), Christian Gorini (UPMC/Sorbonne Universités)

Copyright 2021, SBGf - Sociedade Brasileira de Geofísica

This paper was prepared for presentation during the $17^{\text {th }}$ International Congress of the Brazilian Geophysical Society held in Rio de Janeiro, Brazil, 16-19 August 2021.

Contents of this paper were reviewed by the Technical Committee of the $17^{\text {th }}$ International Congress of the Brazilian Geophysical Society and do not necessarily represent any position of the SBGf, its officers or members. Electronic reproduction or storage of any part of this paper for commercial purposes without the written consent of the Brazilian Geophysical Society is prohibited.

\section{Abstract}

Slope instabilities occur in distinct geological contexts on the marginal basins worldwide and are known for constitute true risks to submarine infrastructure and even to coastal populations, thus representing potential submarine geohazards. In the Offshore Amazon basin, instabilities features and associated mass-transport deposits were already mapped in a series of previous works where (i) quaternary and near-surface remobilized deposits were identified on high-resolution data, occurring interbedded with channel-levee systems on subsurface; and (ii) remobilized masses were also identified as huge vertical stacked deposits on seismic scale, constituting megaslide complexes, throughout the basin.

This paper presents an updated scenario for the distribution of slope instability features in the Offshore Amazon basin, based on the integration of newly geophysical data, with variable resolution. The analysis included the identification and detailing of morphological elements related to failure processes and the interpretation of main echofacies on high-resolution profiles, focusing on the seismic signatures indicative of remobilization processes. The recognition of potential geohazards in the Offshore Amazon basin - considered a new frontier basin in terms of hydrocarbon potential - can subside future projects concerning hazard and risk assessment and can aid the development of exploration and other activities on the basin.

\section{Introduction}

Mass-transport deposits (hereafter MTDs) and related instability features (e.g., slide scars, head and sidewalls, rotated and/or slide blocks) are recurrent architectural elements associated to remobilization processes in a variety of margins and constitute significant volumes of their stratigraphic sections. The investigation of such processes is crucial since the occurrence of slope instabilities can cause major economic and/or environmental/social impacts, such as damages on submarine deep-waters structures, affecting telecommunication and exploration activities (Heezen and
Ewing, 1952; Solheim et al., 2005) and even generating tsunamis waves, a true catastrophic scenario to coastal populations (Tappin et al., 2008). In the petroleum systems, MTDs can constitute seals as well as producing units (Meckel, 2011; Shanmugam, 2006).

In the Foz do Amazonas basin (hereafter Offshore Amazon basin, Figure $1 \mathrm{~A}$ ) pioneer studies were firstly conducted by Damuth and Embley (1981) and Damuth et al. (1988) and later by ODP Leg 155 campaign (Flood and Piper, 1997; Maslin et al., 2005), based on highresolution acoustic data. These authors recognized the occurrence of near-surface quaternary MTDs (Figure 1A) and associated failure features on the central basin ( Amazon fan area), occurring interbedded with welldeveloped channel-levee systems, on subsurface. More recently works, based on regional 2D seismic lines, showed the existence of vertical stacked failure masses, Middle Pliocene-Quaternary in age, with individual thicknesses up to 1000 m thick (Araújo et al., 2009; Reis et al., 2016; Silva et al., 2016). Those MTDs constitute megaslides complexes (MCs), notably distributed on the NW and SE sectors of the Offshore Amazon basin, but also interbedded within the Amazon fan series (Figure 1A). Additionally, the gliding of the upper strata above several décollement surfaces generates a gravity tectonics regime mainly on central fan (Figure 1B), that originate a series of structures that impact seafloor (Silva et al., 1999; Cobbold et al., 1994; Perovano et al., 2011) and that correlates with MTDs structurally-induced (Reis et al., 2016). However, the lack of newly high-resolution acoustic data had prevented until now the refinement of the previous interpretation on recent and/or ongoing seafloor instability processes in the Offshore Amazon basin. Specially in the SE flank of the fan (SE basin slope area), any investigation of near-surface instabilities processes was ever possible so that areas prone to geological hazards remained largely unknown until now.

This work aimed to identify the occurrence, distribution and styles of remobilization associated to near-surface instabilities processes at the slope of the Offshore Amazon basin, in a regional scale. The database included a new grid of $3.5 \mathrm{kHz}$ profiles, along-track multibeam bathymetry and a set of mono and multichannel seismic reflection profiles (acquired by the Brazilian Continental Shelf Survey Programme - LEPLAC), coupled with reinterpretation of the pre-existent $2 \mathrm{D}$ seismic data. The analysis allowed us: (i) to revisit the Amazon fan area, where occurrences of failure events are known since the early 80's; and (ii) to investigate recent and ongoing seafloor instability processes on the SE and NW slopes of the basin, in order to detect areas more prone to geological hazards. This study is a partnership between CAPPES IODP and was used as a subside to the next IODP 
campaign on the Amazon Offshore basin, recently approved.

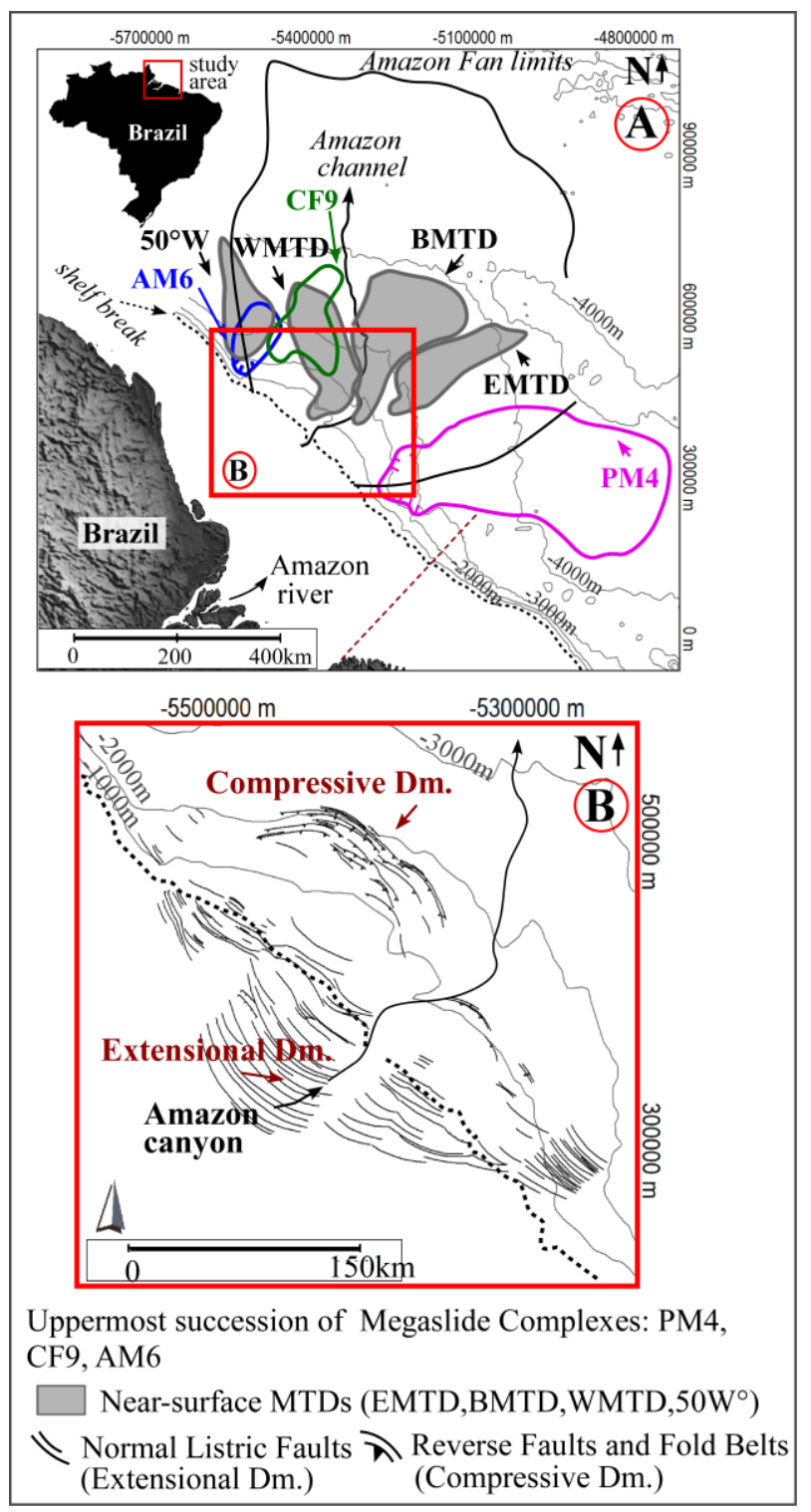

Figure 1 - Simplified map that illustrates the A. masstransport deposits occurrences mapped in the Offshore Amazon basin on previous works and $\mathbf{B}$. the structures generated by the gravity tectonics on the Amazon fan.

\section{Method}

The used dataset comprises: a regional bathymetric and gradient models derived from an updated bathymetric digital model of the Offshore Amazon basin made available by the Directorate of Hydrography and Navigation, Brazilian Navy, based on data compilation from different sources and resolutions (PETROBRAS, the Geophysical Data System (GEODAS (www.ngdc.noaa.gov/mgg/geodas)), General Bathymetric Charts of the Oceans (GEBCO (www.gebco.net)) and bathymetric data from LEPLAC survey Phase II (single- beam and along-track multibeam data)). The database also includes $3.5 \mathrm{kHz}$ sub-bottom profiling from LEPLAC Project and a set of $\sim 20.000 \mathrm{~km}$ of $2 \mathrm{D}$ multichannel seismic, provided by the Brazilian National Agency of Petroleum and Gas (ANP). The seismic grid presents 5 $20 \mathrm{Km}$ of spacing and vertical resolution between $10-100$ $\mathrm{m}$, with record windows $\sim 10 \mathrm{~s}$. All these acoustic data were delivered already processed by the respective entities. Interpretation was conducted according to the main principles of Seismic Stratigraphy (e.g., Catuneanu, 2006). Seismic velocity adopted for calculations was 1600 $\mathrm{m} / \mathrm{s}$, considering minimum values obtained from ODP Leg155 log data for the most superficial strata (Flood et al., 1997).

The employed methodology was threefold: (i) identification of main morpho-bathymetric features indicative of slope mass movements - like headscarps and sidewalls, their lateral extents and heights and seafloor micro-morphologies - through the coupled analyses of bathymetric and gradient models, multibeam bathymetric data, sub-bottom profiling and seismic lines, as done is a variety of studies ((e.g., McAdoo et al., 2000; Minisini et al., 2007; Casalbore et al., 2016)). Due to the low resolution of bathymetric data, scarps vertical reliefs are apparent values (obtained on bathymetric profiles or measured directly from seismic/high-resolution profiles, when possible). Total length mentioned hereafter consists in the distance measured between the upslope shallower scar to the downslope limit of the connected deposit, when possible, as preconized in Clare et al. (2018). To more information about measurements, see Caldas (2020); (ii) echofacies mapping was performed on highresolution profiles $(3.5 \mathrm{kHz})$ in order to identify and detail the nature and extension of exposed MTDs, as discussed on classical case-studies on the literature (e.g., Embley and Jacobi, 1977; Damuth, 1980a; Damuth et al., 1988, among others). Those works mostly correlate remobilization echofacies to transparent and chaotic hyperbolic seismic signatures (Figure 2). Additionally, the MTDs were classified as more disintegrative-like or cohesive-like MTDs (sensu McAdoo et al. 2000), according to key elements, such as the presence of remobilized masses in the interior of source zones (not completely evacuated deposits) and the recognition of blocks within remobilized masses, indicating a minor degree of material fragmentation downslope ; (iii) results from (i) and (ii) above were then compared with MTDs occurrences previous recognized at the scale of $2 \mathrm{D}$ multichannel seismic (like 0.5 to $\sim 1.5 \mathrm{~s}$ twtt depth) described in previous studies (e.g., Araújo et al., 2009; Silva et al., 2016; Reis et al., 2016). Such comparison allowed us to stablish space correlations between the exposed remobilization-related features and deposits, with surface expression on the sea floor (contemplated on this study) with those giant MTDs that compose the uppermost succession of the megaslides complexes (PM4, CF9 and AM6; Figure. 1A) considered already fossilized in the resolution of seismic data. 


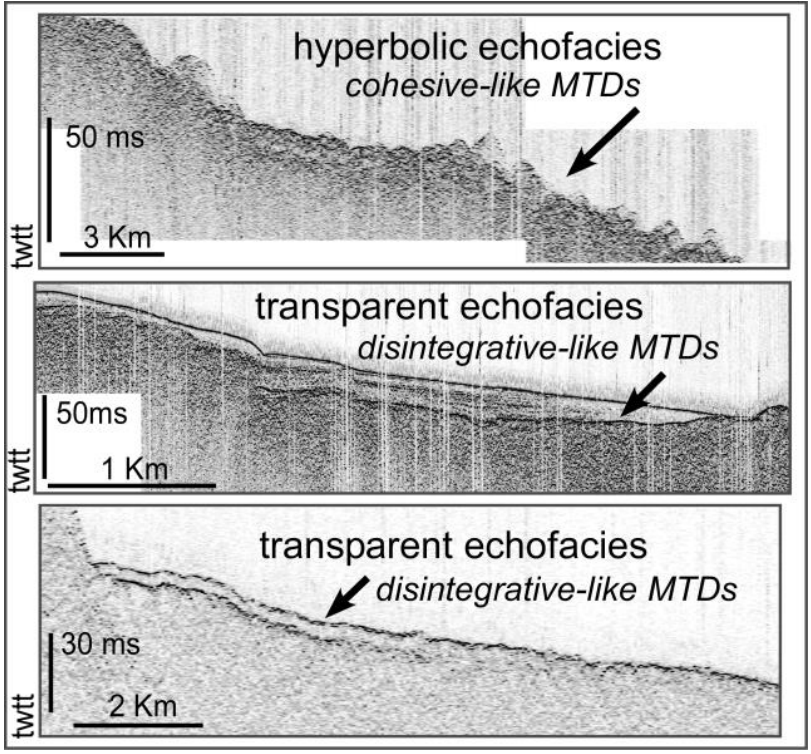

Figure 2 - Examples of slope failure-related echofacies observed on the database (3.5 $\mathrm{kHz}$ profiles).

\section{Results}

The slope of the Offshore Amazon basin clearly shows evidence of recurrent slope gravity-driven processes that extend until deep basin. Our analysis showed the existence of five major erosive features (slide scars) on the slope of the Offshore Amazon basin (Figures 3 and 4 ), located mainly < 3000m depths (upper slope domain). Those scars would be the source for MTDs which distribution were noticed since the interior of the scars and extend to a downslope position. Scarps seen on seismic data exhibit truncated and exposed reflectors, with the lack of any significative sedimentary drape unities - suggesting a relatively recent activity in geological time. The slope can be seen as rather distinct across the basin according to their regional gradient as well as to the nature, vertical relief and lateral extent of their respective geomorphic features indicative of slope disruption, being classified on this study as the SE, Central and NW slopes (Figure 3).

On the steeper SE/NW slopes ( flanks of the Amazon fan, Figures 3 and 4), impressive scars (areas up to 7445 $\mathrm{km}^{2}$ ) indent the shelf break, with maximum gradients between $9-12^{\circ}$. Three main removal zones were mapped (slide scars SE1, SE2 (SE slope) and slide scar NW (NW slope), Figures 3 and 4 ) and scarps up to $800 \mathrm{~m}$ in vertical relief were observed on the data (Figure 5).

The echofacies mapping showed the existence of MTDs on the SE and NW slopes, associated mostly to chaotic hyperbolic echofacies, distributed since the interior of the scar zones. Notably on the SE sector, these MTDs extend until water depths $\sim 4200 \mathrm{~m}$ (Figure 4 ), where gradients are $<1^{\circ}$. The presence of individual coherent blocks defined by shallow faulting on high-resolution and seismic profiles that correlates to a blocky pattern on the multibeam bathymetric data suggests the occurrence of more cohesive-like MTDs (Figure 5). In the NW sector (Figure 4), cohesive-like MTDs were found occurring with lenses of restricted debris flows (disintegrative-like MTDs). Significative total lengths up to $285 \mathrm{~km}$ and 200 $\mathrm{km}$ were observed to the slope mass movements described on the SE and NW, respectively.

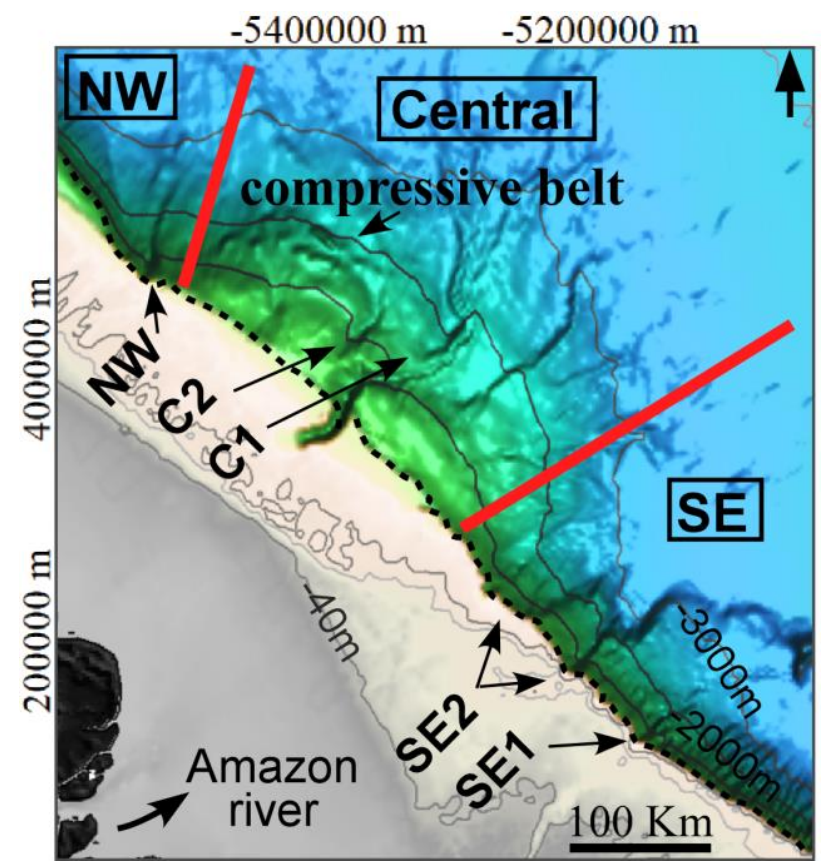

Figure 3 - Main slide scars mapped on the NW, Central and SE slope sectors of Offshore Amazon basin. The dashed black line represents the shelf break; the red lines limit slope sectors defined in this study.

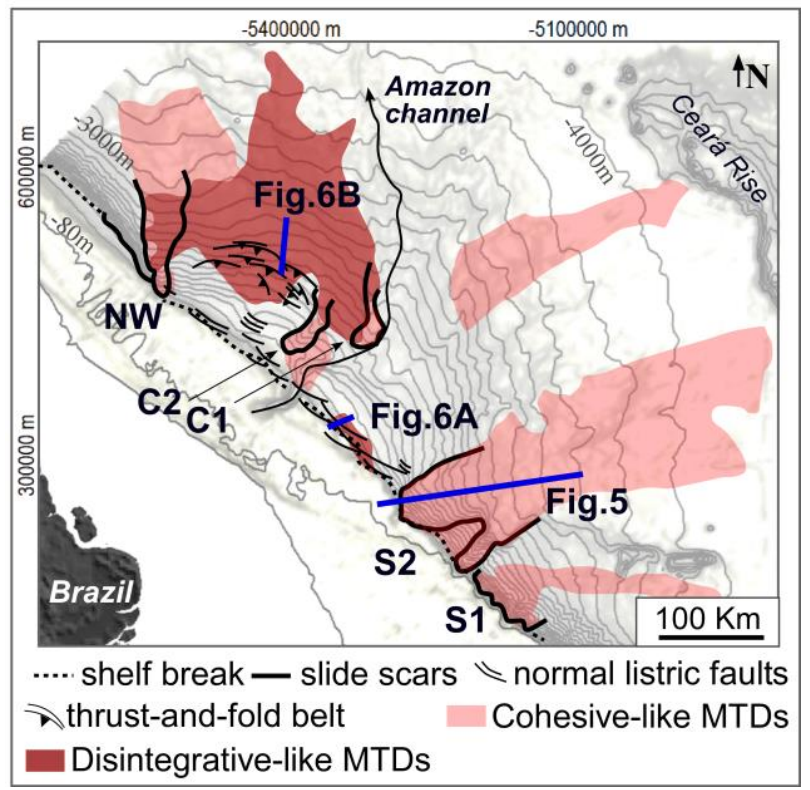

Figure 4 - Main slide scars and MTDs occurrence identified on the slope sectors of Offshore Amazon basin. The dashed black line represents the shelf break.

Contrarily, the Central slope corresponds to the main prograding domain of the Amazon fan, characterized by 
the absence of significative slide scars near the shelf break (Figures 3 and 4). Slope gradients are smoother; with maximum values $\sim 1.5^{\circ}$. Two scars, named slide scars $\mathrm{C} 1$ and $\mathrm{C} 2$ in this study (Figures 3 and 4), were identified on the on the western side of the Amazon canyon-channel system. Smaller in extent (individual areas $<1300 \mathrm{~km}^{2}$ ), those features are restricted to shallower water depths (between 380-2630m). Slide scars C1 and C2 exhibit scarps with vertical reliefs $<180 \mathrm{~m}$ and maximum dips $\sim 3.5^{\circ}$. Both features show homogenous sea floor on the multibeam data, what indicates evacuated slide scars. MTDs were identified inside and contiguous to both scars zones, characterized by an alternation of hyperbolic (on the upper slope proximal zones of slide scars) and transparent echofacies (on distal and deeper zones of slide scars) and extend until $3600 \mathrm{~m}$ depths, in areas with average gradients $\sim 1.7^{\circ}$. Still on the central basin area, on the extensional domain of the gravity tectonics regime, the uplifts associated to the normal listric faults generate structural scarps similar to morphological steps, on the outer shelf/upper slope area (Figures 4 and 6A). Those structures exhibit dips $\sim 2^{\circ}$, with $80-120 \mathrm{~m}$ in relief (Figure $6 \mathrm{~A})$. Contrarily, on the distal NW compressive domain, the fold-and-thrust belt appear as curved lineaments on the sea floor (Figures 4 and $6 \mathrm{~B}$ ), between 1100 to $2220 \mathrm{~m}$ depths. Although structural scarps of the extensional domain were related to highly remolded transparent seismic bodies (debris flows), more fluidized in nature (Figure 6A), it is on the compressive belt that the major deformation is observed. Structural scarps with gradients up to $7.5^{\circ}$ and vertical reliefs between $\sim 350 \mathrm{~m}$ and $680 \mathrm{~m}$ (Figure 6B) were mapped on the high-resolution and seismic profiles, mostly on the NW central basin - where the compressive belt is more developed. Thin (thicknesses $<10 \mathrm{~m}$ ) transparent seismic bodies, interpreted as thinner debris flows (Figure 6B), were noticed in between compressive structures and beyond the fold-and-thrust belt. Those deposits spread for $170 \mathrm{~km}$ downslope in a NW direction, until depths $>\sim 4.000 \mathrm{~m}$, in areas with average slopes $<2^{\circ}$.

When comparing spatial distribution of the exposed MTDs mapped in this study with the Plio-Quaternary megaslide complexes occurrences previously described (Figure 1A) a very similar distribution was noticed, suggesting the persistence and recurrence of slope failure processes over the same localities along geological time.

\section{Conclusions}

This study shows the existence of multiple evidence of slope failures in the Offshore Amazon basin, through the recognition of multiple slide scars and structurally-induced scarps, with hundreds of meters in relief, disposed on the local sea bottom. Related mass-transport deposits vary from more fluidized to blocky in character and reach water depths superior to $4000 \mathrm{~m}$, with spreads of hundreds of kilometers basinward. Slope instabilities processes constitute, thus, an important mechanism of resedimentation and transfer of significative amounts of sediments from shallower to deeper areas in this segment of the margin, coexisting with turbidite architectural elements, such as channel-levee systems that still preserved on the sea bottom. Comparison between exposed and buried MTDs show a great recurrence of those failure events in space over geological time, at least since Plio-Quaternary to Recent.

The results suggest the existence of potential submarine geohazards in the Offshore Amazon basin, with relatively recent activity ( Quaternary), confirming the unstable potential of the margin on slope and deep-water environments.

\section{Acknowledgments}

The authors gratefully acknowledge the support granted during the completion of this study by CAPES (Coordination for the Improvement of Higher-Level Education - Brazil) in the form of PhD. scholarships made to Natalia Caldas and Alberto M. Cruz and financial support for the project (CAPES-IODP, research grant No. 0558/2015). Antonio Tadeu dos Reis and Cleverson Guizan Silva received research grants from the Brazilian National Research Council (CNPq). We are also very grateful to the Brazilian Navy (DHN/LEPLAC) for permission to use LEPLAC seismic lines, as well as to the Brazilian National Agency of Petroleum and Gas (ANP) for supplying seismic data. We also especially thank SMT Kingdom for the use of educational licenses of the software Kingdom Suite $\AA$. This is a contribution of the research group GEOMARGEM: Geology and Oceanography of Passive Continental Margins (http://www.geomargem.org).

\section{References}

ARAÚJO, E.F.S.; SILVA, C.G.; REIS, A.T.; PEROVANO, R., GORINI, C.; VENDEVILLE, B.C.; ALBUQUERQUE, N.C. 2009. Movimentos de massa multiescala na Bacia da Foz do Amazonas - Margem equatorial brasileira. Rev. Bras. Geofís. 27, 485-508.

CALDAS, N.A. 2020. Morfologia, distribuição e mecanismos condicionantes das feições de instabilidade de talude da Bacia da Foz do Amazonas, Margem Equatorial Brasileira. $\mathrm{PhD}$ thesis, $214 \mathrm{f}$.

CASALBORE, D.; BOSMAN, A.; CHIOCCI, F.L.; INGRASSIA, M.; MACELLONI, L.; SPOSATO, A.; MARTORELLI, E. 2016. New Insights on Failure and Post-failure Dynamics of Submarine Landslides on the Intra-slope Palmarola Ridge (Central Tyrrhenian Sea). In: LAMARCHE, G.; MOUNTJOY, J.; BULL, S.; HUBBLE, T.; KRASTEL, S.; LANE, E.; MICALLEF, A.; MOSCARDELLI, L.; MUELLER, C.; PECHER, I.; WOELZ, S. (Eds.). Submarine Mass Movements and their Consequences. Advances in Natural and Technological Hazards Research, v. 41. Cham: Springer. 2016. DOI: 10.1007/978-3-319-20979-19.

CATUNEANU, O. 2006. Principles of Sequence Stratigraphy. 1 ed. Amsterdam: Elsevier.

CLARE, M.; CHAYTOR, J.; DABSON, O.J.; GAMBOA, D.; GEORGIOPOULOU, A.; EADY, H.; HUNT, J.E.; 
JACKSON, C.; KATZ, O.; KRASTEL, S.; LEÓN, R.; MICALLEF, A.; MOERNAUT, J.; MORICONI, R.; MOSCARDELLI, L.; MÜLLER, C.; NORMANDEAU, A.; PATACCI, M.; STEVENTON, M.; URLAUB, M.; VOELKER, D.; WOOD, L.; JOBE, Z. 2018. A consistent global approach for the morphometric characterization of subaqueous landslides. Geol. Soc.: Special Publications, v. $477,455-477$.

COBBOLD, P.R.; MOURGUES, R.; BOYD, K. 2004. Mechanism of thin-skinned detachment in the Amazon Fan: assessing the importance of fluid overpressure and hydrocarbon generation. Mar. Petrol. Geol. v. 21, 10131025. DOI:10.1016/j.marpetgeo.2004.05.003.

DAMUTH, J. E. 1980a. Use of high-frequency (3.5-12 $\mathrm{kHz}$ ) echograms in the study of near-bottom sedimentation processes in the deep-sea: a review. Mar. Geol. v. 38, 51-75. DOI: 10.1016/0025-3227(80)90051-1.

DAMUTH, J.; EMBLEY, R. 1981. Mass-Transport Processes on Amazon Cone: Western Equatorial Atlantic. AAPG Bull., v. 65, 629-643.

DAMUTH, J.; FLOOD, R.; KOWSMANN, R.; BELDERSON, R.H.; GORINI, M. 1988. Anatomy and Growth Pattern of Amazon Deep-Sea Fan as Revealed by Long-Range Side-Scan Sonar (GLORIA) and HighResolution Seismic Studies. AAPG Bull., v. 72, 885-911.

EMBLEY, R.; JACOBI, R. 1977. Distribution and morphology of large submarine sediment slides and slumps on Atlantic continental margins. Mar. Geotechnol., v. 2, 205-228. DOI:10.1080/10641197709379780.

FLOOD, R.; PIPER, D. Amazon Fan Sedimentation: the relationship to equatorial climate change, continental denudation, and sea-level fluctuations. 1997. In: FLOOD, R.D.; PIPER, D.J.W.; KLAUS, A.; PETERSON, L.C. (Eds.). Proceedings of the Ocean Drilling Program, Scientific Results, v. 155, 653-675.

FLOOD, R.D.; PIRMEZ, C.; YIN, H. The Compressionalwave velocity of Amazon Fan Sediments: Calculation from Index Properties and variation with clay content. 1997. In: FLOOD, R.D.; PIPER, D.J.W.; KLAUS, A.; PETERSON, L.C. (Eds.). Proceedings of the Ocean Drilling Program, Scientific Results, v. 155, 477-493.

HEEZEN, B.; EWING, W. Turbidity currents and submarine slumps, and the 1929 Grand Banks [Newfoundland] earthquake. 1952. Am. J. Sci., v. 250, 849-873. DOI:10.2475/ajs.250.12.849.

MASLIN, M.; VILELA, C.; MIKKELSEN, N.; GROOTES, $P$. Causes of catastrophic sediment failures of the Amazon Fan. 2005. Quat. Sci. Rev., v. 24, 2180-2193. DOI:10.1016/j.quascirev.2005.01.016.

MCADOO, B.G.; ORANGE, D.L.; SCREATON, E.; LEE, H.; KAYEN, R 2000. Slope basins, headless canyons and submarine paleoseismology of the Cascadia accretionary complex. Basin Res. 9, 313-324. 1997.
MECKEL, L.D. Reservoir characteristics and classification of sand-prone submarine mass-transport deposits in deepwater settings. 2011. In: SHIPP, R.C.; WEIMER, P.; POSAMENTIER, H.W. (Eds.). Mass Transport Deposits in Deepwater Settings. Tulsa: SEPM Special Publication v.96. 423-452. DOI: 10.2110/sepmsp.096.423.

MINISINI, D.; TRINCARDI, F.; ASIOLI, A.; CANU, M.; FOGLINI, F. 2007. Morphologic variability of exposed mass-transport deposits on the eastern slope of Gela Basin (Sicily channel). Basin Res., v.19, 217-240. DOI: 10.1111/j.1365-2117.2007.00324.x.

PEROVANO, R.; VENDEVILLE, B.; REIS, A.T.; SILVA, C.G.; GORINI, C.; ARAÚJO, E.F.S. 2011. Modelagem física experimental de mecanismos de deformação gravitacional simulando múltiplos intervalos superpressurizados: aplicação à Bacia da $\mathrm{Foz}$ do Amazonas. Rev. Bras. Geofís., v. 29, 583-607. DOI:10.22564/rbgf.v29i3.101.

REIS, A.T.; ARAÚJO, E.; SILVA, C.; CRUZ, A.M.; GORINI, C.; DROZ, L.; MIGEON, S.; PEROVANO, R.; KING, I.; BACHE, F. 2016. Effects of a regional décollement level for gravity tectonics on late Neogene to recent large-scale slope instabilities in the Foz do Amazonas Basin, Brazil. Mar. Pet. Geol., v.75, p. 29-52. DOI: 10.1016/j.marpetgeo.2016.04.011.

SHANMUGAM, G. 2006. Deep-Water Processes and Facies Models: Implications for Sandstone Petroleum Reservoirs (Handbook of Petroleum Exploration and Production,5). 1 ed. Amsterdam: Elsevier.

SILVA, S.; MACIEL, R.; SEVERINO, M. 1999. Cenozoic tectonics of Amazon Mouth Basin. Geo. Mar. Lett. 18, 256-262. DOI: 10.1007/s00367005 0077.

SILVA, C.C.; REIS, A.T.; PEROVANO, R.; GORINI, M.A.; SANTOS, M.; JECK, I.K.; TAVARES, A.; GORINI, C. 2016. Multiple Megaslide Complexes and Their Significance for the Miocene Stratigraphic Evolution of the Offshore Amazon Basin. In: LAMARCHE, G.; MOUNTJOY, J.; BULL, S.; HUBBLE, T.; KRASTEL, S.; LANE, E.; MICALLEF, A.; MOSCARDELLI, L.; MUELLER, C.; PECHER, I.; WOELZ, S. (Eds.). Submarine Mass Movements and their Consequences. Advances in Natural and Technological Hazards Research, v. 41. Cham: Springer. 2016. DOI: 10.1007/978-3-319-20979-1 5.

SOLHEIM, A.; BERG, K.; FORSBERG, C.; BRYN, P. 2005. The Storegga Slide complex: repetitive large scale sliding with similar cause and development. Mar. Petrol. Geol., v.22, 97-107. DOI:10.1016/j.marpetgeo.2004.10.013.

TAPPIN, D. R.; WATTS, P.; GRILLI, S. T. 2008. The Papua New Guinea tsunami of 17 July 1998: anatomy of a catastrophic event. Nat. Haz. Ear. Syst. Sci., v.8, 243266. 


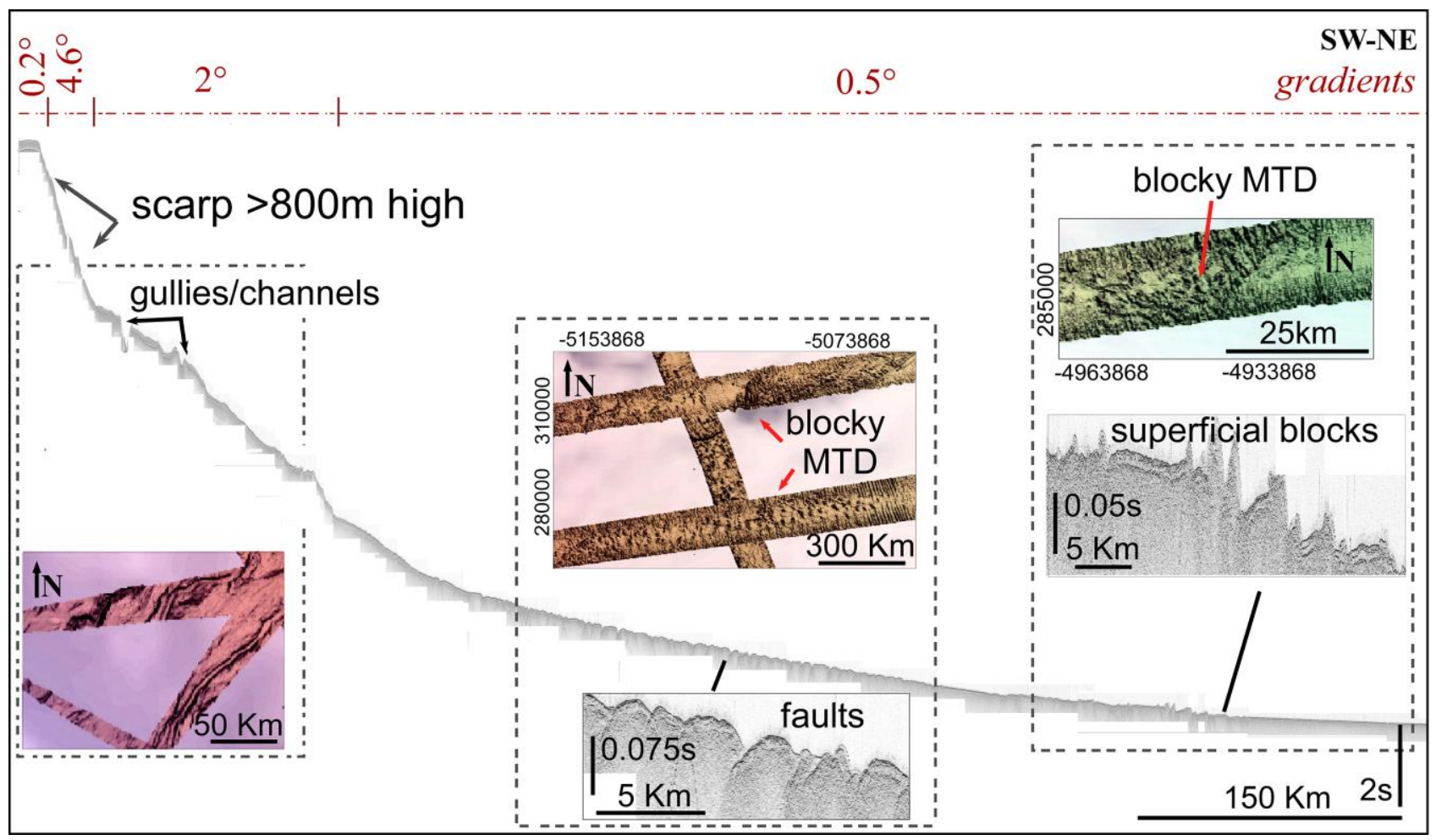

Figure 5 - Slide scar SE2 (SE slope), characterized by expressive reliefs and gradients, with MTDs occurrence downslope. Shallow faulting defines individual superficial blocks, indicating more-cohesive like MTDs. Profile location in Figure 4.

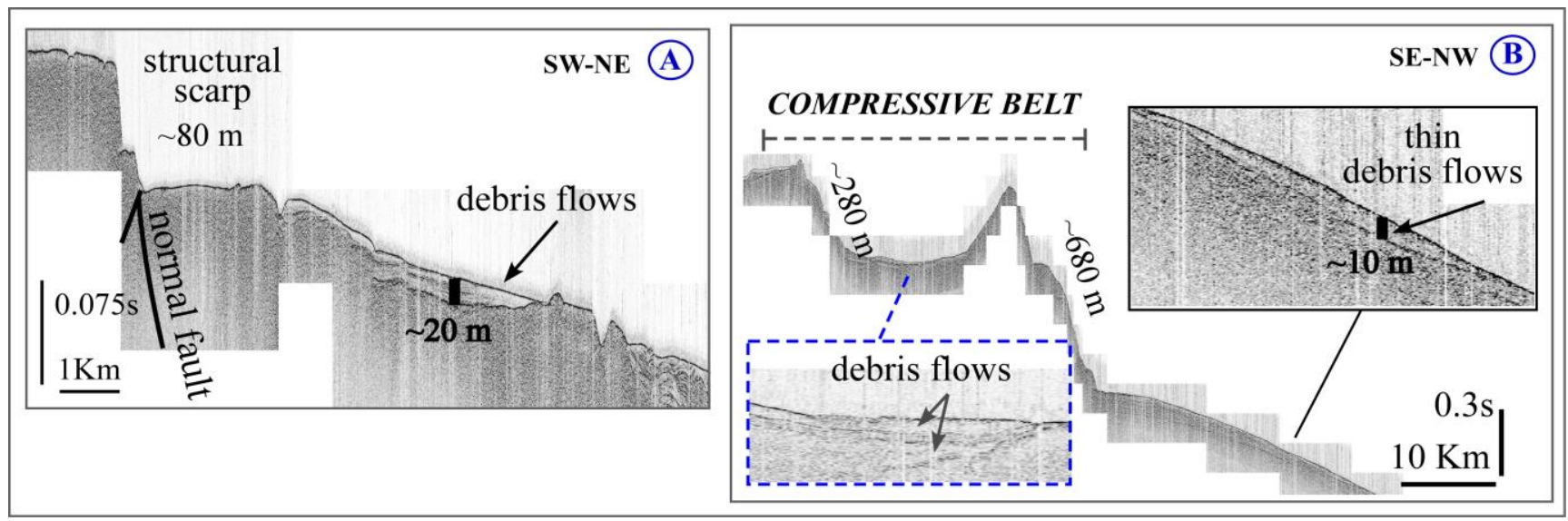

Figure 6 - Gravity tectonics structures with seabed expression, on central slope. Disintegrative-like MTDs prevail over central fan, related to structural scarps. A. Normal listric faults and contiguous debris flows (disintegrative-like MTDs); B. Thrust-andfold belt, with structural scarps with hundreds of meters high. Thin MTDs $(<10 \mathrm{~m}$ thicknesses) were found in between and contiguous to the compressive structures. Profiles location in Figure 4. 